\title{
Locus of control and the labor market
}

\author{
Deborah A Cobb-Clark ${ }^{1,2}$
}

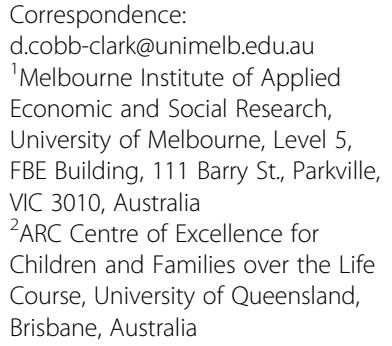

\author{
Abstract \\ This paper reviews the role of locus of control in the labor market. I begin with a \\ discussion of the conceptual origins of locus of control, including its relationship to \\ related concepts such as self-efficacy, motivation, and self-control. The relationship \\ between locus of control and labor market success is then summarized. In doing so, \\ I pay careful attention to what we know about three potential mechanisms - human \\ capital investments, hiring decisions, and optimal incentive contracts - through \\ which locus of control might operate. Finally, the broader implications of these \\ relationships for public policy and future research are discussed. \\ JEL codes: J18; J20; J24 \\ Keywords: Locus of control; Labor markets; Human capital
}

\section{Introduction}

One of the most exciting developments in labor economics over the past decade has been the reframing of standard theoretical and empirical models to accommodate the role of non-cognitive skills in driving labor market outcomes. What began as a simple recognition that non-cognitive skills - for example, personality traits, perseverance, locus of control, self-efficacy, self-esteem, social skills, etc. - often have predictive power in wage equations has evolved into a considered analysis of the mechanisms through which non-cognitive skills impact worker and firm decisions in general. The result has been a more profound understanding of the way that labor markets work and a more nuanced view of what it takes to be successful.

The objective of this paper is to synthesize the emerging research on one noncognitive skill: locus of control. ${ }^{1}$ Locus of control is perhaps best described as "a generalized attitude, belief, or expectancy regarding the nature of the causal relationship between one's own behavior and its consequences" (Rotter 1966 p.2). Those believing that life's outcomes are due to their own efforts have an internal locus of control, while those believing that outcomes are due to external factors (e.g., luck) have an external locus of control..$^{2}$ Perceptions of control have long had a prominent place in psychology, with psychologists arguing that an individual's belief that his or her actions will lead to the desired outcome is fundamental to both motivation (i.e., effort) (Bandura 1986, 1989; Skinner 1996; Goldsmith et al. 2000) and self-control (Rosenbaum 1980).

Economists have been much slower than psychologists to turn to locus of control as a means of understanding human behavior. Nonetheless, locus of control has increasingly come to be regarded as one of the core concepts in many fields of applied economics, including labor economics. Having an internal locus of control has a demonstrable link with 
labor market success and appears to be central to many of the human capital investment decisions which consume the attention of labor economists. In particular, investments in education, health, self-employment, and job search have all been linked to individuals' beliefs about the extent to which they control life's outcomes. Research in organizational sciences demonstrates that the decisions a senior manager makes are driven in part by his or her locus of control, and there is the potential for locus of control to become an important screening device in the hiring process. Finally, as one component of self-control more generally, locus of control is also relevant for understanding the types of incentive contracts that firms offer their workers.

This review begins with a discussion of the conceptual origins of locus of control, including its relationship to related concepts such as self-efficacy, motivation, and selfcontrol (see Section 2). In Section 3, the relationship between locus of control and labor market success is summarized. Section 4 pays careful attention to what we know about three potential mechanisms - human capital investments, hiring decisions, and optimal incentive contracts - through which locus of control might operate. The broader implications of these relationships for public policy are discussed in Section 5. Finally, conclusions and directions for future research are outlined in Section 6.

\section{The conceptual origins of locus of control}

The concept of locus of control emerged out of social learning theory more than 50 years ago. In his seminal work, Rotter (1954) proposed a theory of learning in which the reinforcement (i.e., reward or punishment) of a behavior strengthens individuals' expectancy (expectation) that this particular behavior will be reinforced in the future. The anticipation of future reinforcement is increased more, however, when individuals believe that the current reinforcement is contingent upon their own behavior than when they do not. As individuals differ in the reinforcement that they have received in the past, Rotter argued that they will also differ in the degree to which they generally attribute reinforcement to their own actions and that these beliefs regarding the internal versus external nature of reinforcement constituted a personality trait (Rotter 1966). ${ }^{3}$

In the intervening years, locus of control has become one of the most frequently studied concepts in psychology (Rotter 1990; Lefcourt 1992). With conceptual links to both motivation and self-control, locus of control is also an increasingly important construct for understanding a wide range of economic decisions.

\subsection{What are we really measuring?}

Today psychologists distinguish between and measure several closely-related concepts locus of control, self-efficacy, self-esteem, neuroticism, perceived behavioral control, selfmastery, etc. Although voluminous literatures on each have evolved somewhat independently, Judge et al. (2002) conclude that in fact locus of control, self-efficacy, and neuroticism are all markers of the same higher order concept. Moreover, they argue that - along with self-esteem - these three constructs form the basis for individuals' core self-evaluations, i.e., their fundamental assessment about themselves and their own self-worth (e.g., Judge et al. 2003). Similarly, Ajzen (2002) argues that locus of control and self-efficacy together form a broader concept that can be referred to as "perceived behavioral control". Locus of control reflects individuals' beliefs about whether what happens in life is causally determined by their own decisions and behavior, while self-efficacy captures the extent to which individuals 
believe that they personally are capable of undertaking a particular behavior. Self-efficacy is generally context-specific because it is related to the perceived difficulty of a particular action or behavior, while locus of control is a general skill that is thought to be stable across situations (Ajzen 2002). Finally, Pearlin and Schooler (1978) propose a measure of "selfmastery" which combines elements of both locus of control and self-efficacy. ${ }^{4}$

Economists have largely ignored these distinctions, often simply relying on the measures available to them which frequently combine elements of multiple concepts. This ambiguity about what is actually being measured has been amplified by the fact that there are many different scales - which have varied over time - for measuring each of these psychological concepts. In addition, economists are almost always working with incomplete scales because the complex multi-layered scales requiring numerous data items that psychologists typically propose are often not well-suited to the sorts of large-scale secondary survey data sets that economists favor. ${ }^{5}$ Finally, economists typically focus on generalized measures of perceived control which are largely independent of the context. In contrast, psychologists often rely on locus of control measures which are specific to particular domains, e.g., health (Wallston et al. 1978), work (Spector 1988), or finances (Furnham 1986), with perceived control measures for as many as 18 different domains existing by the early 1990s (Lefcourt 1992).

Economists' laissez-faire approach to measurement has had both advantages and disadvantages. On the one hand, ignoring the measurement challenge has allowed the economic research to progress and has enabled a body of work to emerge. While there is no single, complete control measure widely available in the data economists typically rely on, a subset of relevant items have been included in a surprising number of data sources. By disregarding the subtleties of the distinctions that psychologists are inclined to make, economists have been able to make progress by ignoring the trees in order to see the forest. On the other hand, because they have failed to distinguish between related concepts and to take measurement seriously, economists' understanding of the way that perceptions of control influence economic behavior lacks a certain richness and complexity. ${ }^{6}$

Finally, it is important to note that locus of control - and indeed other measures of personality - are not simply proxies for the standard risk, time, and social preferences which economists use to characterize individuals' utility functions. Almlund et al. (2011), for example, point out that any empirical associations are not consistent across studies, and often preference measures are uncorrelated with intuitively similar personality traits. Locus of control is significantly correlated with negative reciprocity, trust, risk and time preferences, and altruism in the German population as a whole, but continues to explain life satisfaction, educational attainment, health, and labor market outcomes even accounting for these economic preferences (Becker et al. 2012). Finally, Borghans et al. (2008) argue that personality traits - like cognitive ability - can impose constraints on individuals' choices and that "conventional economic preference parameters can be interpreted as consequences of these constraints" (pg. 977).

\subsection{Locus of control and motivation}

Unless people believe that they can produce desired effects and forestall undesired ones by their actions, they have little incentive to act. Whatever other factors may operate as motivators, they are rooted in the core belief that one has the power to produce the desired results (Bandura 2000, p.120). 
Psychologists see perceptions of control as integral to motivation and, hence, human behavior. Atkinson's (1964) theory of motivation, for example, views motivation as the product of two key components - motives and expectancies. A motive is the general tendency to approach (or avoid) a type of incentive, while an expectancy is an individual's assessment of the chances that his or her actions will lead to the desired outcome (Hill et al. 1985). Similarly, Bandura (1989 p.1176) argues that a person's self-efficacy determines "their level of motivation, as reflected in how much effort they will exert in an endeavor and how long they will persevere in the face of obstacles". In fact, Skinner (1995) asserts that the primary mechanisms through which perceived control influences outcomes are motivation and coping.

While psychologists have devoted considerable attention to the links between perceived control and motivation, economists have largely proceeded as through motivation is completely synonymous with incentives, i.e., costs and benefits. Motivation is sometimes acknowledged as one of the "soft skills" that is fundamental to life success (e.g., Duncan and Dunifon 1998; Goldsmith et al. 2000). However, in the end, economists usually treat motivation as one component of unobserved, individual-specific heterogeneity more generally.

Economists' lack of attention to motivation per se is interesting in light of the way that locus of control measures came to be included in large panel data sets. In particular, the designers of the Panel Study of Income Dynamics (PSID) decided to measure motivation directly because they had a specific interest in poverty dynamics. ${ }^{7}$ They were heavily influenced by psychologists' expectancy theory of motivation (see Goldsmith et al. 2000 for a review), and the motivation measures included in the PSID were guided by Atkinson's (1964) theory of motivation (Hill et al. 1985; Duncan and Dunifon 1998). Although psychologists often see expectancy in terms of individuals' beliefs about their ability to succeed in specific tasks (e.g., Bandura 1986), both the PSID and National Longitudinal Survey (NLS) include items from Rotter's (1966) theory of generalized locus of control (Duncan and Dunifon 1998; Dunifon and Duncan 1998). ${ }^{8}$ Measures of locus of control have subsequently been included in a number of other household panel surveys including the Household Income and Labour Dynamics in Australia (HILDA) Study and the German Socio-Economic Panel (SOEP).

If perceived control underpins intrinsic motivation, as the psychologists assert, then it is hardly surprising that economists are finding that locus of control predicts a vast array of economic and social outcomes. At the same time, the mere existence of an association is not particularly informative about the underlying mechanism producing the relationship. $\mathrm{Ng}$ et al. (2006) undertake an interesting meta-analysis of the relationship between locus of control and work outcomes in an effort to shed light on the pathways that link the two. They find support for the hypothesis that locus of control is related to job motivation, but also for links between locus of control and employees' well-being and efforts to assert control at work.

\subsection{Locus of control and self-control}

Self-control refers to the capacity for altering one's own responses, especially to bring them into line with standards such as ideals, values, morals, and social expectations, and to support the pursuit of long-term goals (Baumeister et al. 2007, p.351). 
Like motivation, self-control - alternatively self-regulation or self-discipline - has also been at the core of research in psychology for decades. In their meta-analysis, for example, Duckworth and Kern (2011) identify over 100 unique self- and informant-reported questionnaires designed to measure self-control either on its own or as a subscale of broader personality inventories. Some of these draw a direct link between self-control and perceptions of control.

In particular, Rosenbaum's (1980) Self-Control Schedule (SCS) is a survey instrument designed to assess people's self-reported tendencies to apply self-control to solve behavioral problems. One of the four self-controlling behaviors captured in the SCS is perceived self-efficacy. Drawing on Bandura's (1977) model of behavioral change, Rosenbaum argues that "before a person applies any specific self-controlling skill he must believe that he can control his own behavior without outside help" (p.111). ${ }^{9}$

This conceptual link between locus of control and self-control is important because economists are increasingly incorporating the notion of temptation and self-control into models of inter-temporal decision making. A vast array of decisions have been considered including consumption and savings decisions (e.g., Thaler and Shefrin 1981; Shefrin and Thaler 1988; Levin 1998), criminal behavior (Lee and McCray 2005), overeating (Ruhm 2012), consumer pricing decisions (Esteban et al. 2007), welfare receipt (Chan 2014), and worker compensation (Kaur et al. 2010, 2011; Parsons and Van Wesep 2013).

In each case, greater self-control supports individuals in resisting immediate temptation (i.e., choices with immediate payoffs and long-term costs) and in making longterm investments (i.e., choices with immediate costs and long-term payoffs). If selfcontrol is enhanced by the belief that what one does matters (i.e., an internal locus of control) and is diminished by the belief that what happens is a matter of luck (i.e., an external locus of control), then self-control may be another pathway linking locus of control to many of life's outcomes.

\section{On the importance of being internal}

When people perceive that they have a high degree of control, they exert effort, try hard, initiate action, and persist in the face of failures and setbacks; they evince interest, optimism, sustained attention, problem solving, and an action orientatio. (Skinner 1996 p. 556).

There is compelling evidence that having an internal locus of control is associated with labor market success. Workers with positive core self-evaluations (i.e., an internal locus of control) seek out more complex jobs (Judge et al. 2000), have better job performance (see Judge and Bono 2001), and are particularly good at capitalizing on the advantages associated with having a good education and an advantaged family background (Judge and Hurst 2007). Those with an internal locus of control also tend to set more challenging goals, persist in the face of adversity, experience less job stress, and be more successful generally (see Ng et al. 2006; Wang et al. 2010).

It is no surprise then that having an internal locus of control has been linked with higher earnings (e.g., Heineck and Anger 2010; Piatek and Pinger 2010; Semykina and Linz 2007; Osborne Groves 2005; Osborne 2000; Goldsmith et al. 1997; Duncan and 
Dunifon 1998; Andrisani 1977, 1981), faster earnings growth (Schnitzlein and Stephani 2013), and greater job satisfaction ( $\mathrm{Ng}$ et al. 2006). Job seekers with an internal locus of control also have a higher probability of reemployment and shorter unemployment durations following job loss (Gallo et al. 2003; Uhlendorff 2004). In addition, locus of control is related to occupational attainment (Andrisani 1977; Cobb-Clark and Tan 2011), the pace of occupational advancement (Andrisani 1977), and the propensity to become self-employed (Hansemark 2003; Caliendo et al. 2014). Entrepreneurs - though not employees - with an internal locus of control enjoy higher wage returns to education than do their more external counterparts (Van Praag et al. 2009). Finally, full-time workers experiencing a health shock are more likely to remain in the labor force and work full-time if they have an internal locus of control (Schurer 2014).

It is important to note that there are often important gender differences in the way that locus of control is related to labor market outcomes. For example, Semykina and Linz (2007) find a positive association between the locus of control and wages of Russian women, though not for Russian men. In contrast, Cobb-Clark and Tan (2011) find that women's occupational attainment is not linked to their locus of control, while men with an external locus of control are less likely to be managers or education professions and are more likely to be employed as cleaners or factory workers. Similarly, men (though not women) with an internal locus of control are significantly more likely to start a new business (Hansemark 2003). Finally, Goldsmith et al. (1996) conclude that young women's, but not young men's, locus of control is influenced by previous labor market experiences.

Finally, having an internal locus of control is not always a positive attribute in the workplace. In his meta-analysis, Avtgis (1998) found that workers with an internal locus of control were less susceptible to influence, less easily persuaded, and less likely to conform than their co-workers with an external locus of control. This is likely to be an advantage in some contexts, but a disadvantage in others.

\section{How might locus of control influence labor market outcomes?}

Economists' early studies of non-cognitive (a.k.a. 'soft' or 'character') skills, such as locus of control, personality traits, self-esteem, resilience, etc., typically focused on estimating the returns to particular skill endowments. The channels linking non-cognitive skills to economic success were usually relegated to a black box in an effort to demonstrate the predictive power of non-cognitive skills more generally. In recent years, economists have begun to explicitly incorporate non-cognitive skills directly into economic models of decision making in an effort to understand why they matter (e.g., Borghans 2008; Almlund et al. 2011).

In what follows, I consider three possible mechanisms linking locus of control to labor market outcomes: i) human capital investments; ii) firm hiring decisions; and iii) optimal incentive contracts.

\subsection{Human capital investments}

In 1966, the 'Coleman' Report found that locus of control was more highly related to achievement than any other factor in the student's background or school (Coleman 1971) (as quoted in Coleman and DeLeire 2003). 
Individuals' perceptions of control are intricately linked to the human capital investments they make. In fact, much of the effect of locus of control on labor market outcomes, in particular wages, may operate indirectly through the decisions individuals make to acquire productive skills (Heckman et al. 2006; Piatek and Pinger, 2010). There are large literatures, for example, documenting the relationship between locus of control and academic performance (e.g., Wang et al. 1999; Heckman and Kautz 2012; Mendolia and Walker 2014b); health behaviors (e.g., Wallston et al. 1978; Steptoe and Wardle 2001; Chiteji 2010; Cobb-Clark et al. 2014; Mendolia and Walker 2014a); and employment-related training (Offerhaus 2013). ${ }^{10}$

Coleman and DeLeire (2003) were the first to theorize that locus of control affects educational outcomes by influencing adolescents' beliefs about the returns to education. Rather than modelling locus of control as a direct wage determinant - as the previous literature on motivation had done - they instead draw a link between locus of control and expected wage outcomes. Specifically, they argue that young people with an internal locus of control believe that education increases the probability of earning a high wage by more - i.e., believe the wage returns to education are higher - than do similar young people with an external locus of control. As a result, they are expected to invest more in education than their external peers. Coleman and Deleire provide empirical evidence that U.S. adolescents with an internal locus of control do in fact anticipate higher wage returns to additional years of education. ${ }^{11}$

The notion that locus of control is linked to the human capital investment decision through individuals' beliefs about investment returns has also been studied in the context of job search. Specifically, McGee (2014) investigates the role of locus of control in job search and finds that young unemployed men with an internal locus of control set higher reservation wages and search more intensively. Unfortunately, he lacks a direct measure of individuals' beliefs about the payoffs. However, McGee argues that locus of control must operate through beliefs about the returns to search rather than productivity per se because internal job seekers are no better at converting search effort into job offers and earn no more than their peers upon finding employment.

Similarly, Caliendo et al. (2015) develop a job search model in which locus of control drives individuals' subjective beliefs about the effect of their search effort on the job offer arrival rate. They then compare the theoretical predictions from this model to those derived from a competing model in which an internal locus of control increases the offer arrival rate irrespective of individuals' search intensity. While the former model predicts that internal job seekers will search more intensively, the latter model predicts they will engage in less job search. The authors then provide empirical evidence that internal job seekers both have higher reservation wages and search more intensively. Moreover, the marginal effect of an additional job application on individuals' propensity to report that they are very likely to get a job in the next period is higher among those job seekers with an internal locus of control. These results are consistent with locus of control influencing job search through individuals' subjective beliefs about the payoffs to search.

Finally, McGee and McGee (2011) provide experimental evidence that job search is linked to locus of control in the absence of information about the impact of search effort on job offers. This link disappears, however, when subjects are told the exact relationship between effort and offers. Importantly, the authors' experimental design rules out several 
alternative explanations (i.e., unmeasured human capital, personality traits, or search costs) for the relationships between locus of control, reservation wages, and search intensity.

Given the critical importance of human capital in driving labor market success, it would be useful for future researchers to consider whether locus of control and other types of human capital investments are also linked through individuals' beliefs about investment returns.

Even more importantly, there is a great deal of work to be done in investigating the extent to which other mechanisms would also - or would perhaps better - explain the role of locus of control in human capital investment decisions. For example, Salamanca et al. (2015) demonstrate that households with an internal economic locus of control are more likely to invest in risky assets. The authors argue that their results stem from disparity in risk perceptions. Those who have an internal economic locus of control simply perceive less variance in risky assets, which makes these assets more attractive. As human capital investments are also risky, this raises questions about whether locus of control also influences human capital acquisition through risk perceptions. Moreover, the conceptual links between locus of control, motivation, and self-control point to other potential pathways between locus of control and human capital acquisition. In particular, DellaVigna and Paserman (2005) and Paserman (2008) provide evidence that many job seekers have time inconsistent preferences, i.e., self-control issues, and as a result tend to procrastinate in searching for work.

Understanding the relative importance of these alternative pathways - i.e., expectations regarding returns, perceptions of risk, self-control, motivation, etc. - would be extremely valuable in the design of policies to promote human capital investments. In particular, it is not immediately apparent that there is a single magic bullet which is likely to be optimal irrespective of the underlying mechanism.

\subsection{Firm hiring decisions}

Potential employers frequently use personality tests to screen applicants' suitability for positions within their organizations. Although personality tests have been around since they were adopted by the U.S. military in World War I, their use in the workplace expanded dramatically after 1998 when U.S. federal law banned the use of polygraphs by employers (Stabile 2002). A 2003 survey, for example, found that 30 percent of U.S. companies, ranging from small businesses to major corporations, were using personality tests to screen job applicants (Heller 2005). In short, personality testing is big business and is growing rapidly (Hsu 2004).

Firms use personality tests because they can be an inexpensive way to gain insights into potential employees that they would not otherwise have. Importantly, the widespread acceptance of a simple taxonomy for describing personality - i.e., the Big Five was instrumental in reigniting organizational psychologists' enthusiasm for studying the potential efficacy of personality testing (Mount and Barrick 1998). Reviewing the results from a number of meta-analyses conducted in the 1990s, Rothstein and Goffin (2006) conclude that - despite the controversy surrounding them - personality measures may be an important predictor of job performance.

While much of the organizational psychology literature focuses solely on the Big Five, there is also evidence that locus of control is related to job performance (e.g., Judge 
and Bono 2001). Spector (1982) reviews a number of studies and concludes that "internals do perform better than externals," but only if they perceive that "effort will lead to valued rewards" (p.489). Although internals are likely to have a greater expectation that performance will result in a reward, they may not, in fact, value the reward, leading their performance to be no better than that of their external co-workers. ${ }^{12}$

The way in which those with an internal locus of control approach their jobs yields important insights into why locus of control is linked to so many labor market outcomes. Spector (1982), for example, notes that "not only do internals perceive greater control, but they will actually seek out situations in which control is possible" (p.483). Decision makers with an internal locus of control are less likely than their external counterparts to rely on statistical or mechanical models rather than their own judgment - unless they have been involved personally in the development of the model (Kaplan et al. 2001). Moreover, managers with an internal locus of control tend to consult others, but then make decisions themselves, while managers with an external locus of control tend to rely on participative decision-making in which a group of individuals is expected to define the problem and reach consensus on the solution (Selart 2005). Finally, more internal chief executives tend to pursue more innovation, undertake greater risks, and lead rather than follow competitors (Miller et al. 1982).

The widespread use of personality testing in hiring decisions raises a number of important research questions. In particular, how much sorting across industries, occupations, firms, labor markets, etc. occurs as a result? What are the implications of this screening process for racial and gender equity in career progression, earnings trajectories, and the like? What is the link between personality and organizational position given that certain traits like locus of control seem better placed in some functions (e.g., managerial roles) rather than others? Given the importance of job ladders, does locus of control matter more at certain points in workers' career trajectories than others?

\subsection{Optimal incentive contacts}

Before the Industrial Revolution in Britain most workers controlled their pace, timing, and conduct at work. Factory discipline radically changed this ... discipline succeeded mainly by increasing work effort. Workers effectively hired capitalists to make them work harder. They lacked the self-control to achieve higher earnings on their own (Clark 1994 p.128).

There is a small, but growing, economics literature which attempts to understand the ways that firms can use incentive contracts - i.e., compensation policies - to manage workers with self-control problems. ${ }^{13}$ Given the conceptual links between self-control, motivation, and locus of control, it is illustrative to consider what insights this emerging literature has to offer about the relationship between locus of control and labor market success.

Bowles et al. (2001) view an internal locus of control as a type of incentive-enhancing preference that leads internal workers to work harder, ceteris paribus. More fatalistic workers, i.e., those with an external locus of control, on the other hand, believe that their own work effort has less effect on the probability of losing their jobs. Thus, 
greater fatalism reduces the subjective marginal benefit to exerting effort, thereby reducing desired effort levels.

A lack of self-control among workers can also lead to shirking and reduced productivity. Economists typically model self-control problems either as i) time-inconsistent (i.e., present-biased) preferences (e.g., Laibson 1997; O’Donoghue and Rabin 1999; DellaVigna 2009) or ii) a dual preference structure in which agents are simultaneously farsighted planners and myopic doers (Thaler and Shefrin 1981). Willpower represents the psychic cost of exercising the self-control necessary to resist immediate gratification and achieve ones long-term goals (Shefrin and Thaler 1988).

A number of factors are relevant for the design of optimal compensation policy in the face of workers' self-control problems (see Gilpatric 2008; Kaur et al. 2010; 2011; Jain 2012). First is the degree of workers' present-bias; the greater the present-bias, the sharper is the required trade-off between compensation and effort, and the more costly it is for firms to motivate workers. Second is the extent to which firms are allowed to punish workers who shirk, e.g., through dismissal or withholding pay. Third is the extent to which workers either understand (i.e., are sophisticated) or do not understand (i.e., are naïve) that they have self-control issues. Sophisticated workers' may prefer more limited choice sets - for example, compensation schedules with commitment devices, e.g., quotas, which assist in maintaining self-control. ${ }^{14}$ Fourth is the extent to which contracting occurs over multiple periods. The final factor is the distribution of time-consistent versus present-biased preferences; workers who do not have self-control issues may receive rents if firms attempt to motivate those who do.

Taking these factors into account, firms can then induce worker effort by strategically choosing: i) the timing of compensation, i.e., the delay between effort and pay; ii) the penalty for low effort; iii) the range of decisions over which workers need to exert selfcontrol; and iv) the social dimensions of the work environment (see Kaur et al. 2010; Jain 2012; Parsons and Van Wesp 2013).

To date, there appears to be no corresponding research specifically linking workers' locus of control to the design of firms' compensation policies. Yet given the conceptual links between locus of control, on the one hand, and self-control and motivation, on the other, it is clear that the challenges in motivating workers' lacking in self-control are equally pressing when considering workers with an external locus of control. In particular, it will be very difficult for firms to incentivize workers if they believe that their rewards, e.g., pay or promotions, will be the result of luck or supervisor eccentricities rather than their own effort (see Bowles et al. 2001). Thus, optimal compensation rules will also depend on the degree to which workers have internal versus external perceptions of control.

Also important are the insights from a related literature that considers the interactions between preference heterogeneity and incentive contracts (see Dohmen 2014 for a review). In particular, workers sort themselves into alternative compensation schemes partially on the basis of their economic preferences, and these choices have important implications not only for workers themselves but also for aggregate workforce composition. It is an open question whether a similar sorting occurs with respect to workers' perceptions of control. Locus of control is associated with occupational sorting, for example, but it is unclear whether this is the result of firms using locus of control as a screening device in their hiring decisions or workers taking compensation arrangements 
into account when choosing occupations. It is not that hard to imagine for example, that individuals with an internal locus of control might be more inclined to choose steeper compensation schedules which heavily reward their own effort - as they might if they were aware of their own self-control issues.

Future research which assesses the extent to which locus of control is linked to labor market outcomes, e.g., wages, occupation, etc., through the design of and selection into incentive contracts would be particularly useful.

\title{
5 What are the implications of locus of control for policy development
}

\author{
Labor market policies succeed or fail at least in part depending on how well they \\ reflect or account for behavioral responses (Babcock et al. 2012).
}

As traditional economic models of decision-making give way to models with more realistic psychological foundations, there is a pressing need to carefully consider what this 'behavioral' approach implies for public policy. Two issues are particularly relevant. First, the emergence of specific non-cognitive skills, like locus of control, conscientiousness, grit, etc. as facilitators of economic and social well-being points to the potential efficacy of directing assistance towards - and investing in - individuals lacking those skills. Second, the explicit recognition of agents' self-control issues breaks the traditional correspondence between revealed preferences and normative preferences, making it possible for paternalistic regulation to improve welfare by helping individuals avoid choices that they will later regret.

A thorough discussion of the emerging literatures in behavioral public policy and behavioral welfare economics is beyond the scope of this review. ${ }^{15}$ Instead, in what follows, I focus on the implications of locus of control specifically, and self-control more generally, for the development of labor market policy. I also consider what we know about the potential for locus of control to be improved through targeted interventions.

\subsection{Labor market policy}

As conceived by Rotter, locus of control captures individuals' perceptions of the causal link between their own actions and what happens subsequently. Those who believe that external factors (e.g., luck or powerful others) drive outcomes will also believe that the returns to exerting effort are lower and will, therefore, be harder to motivate. This link between locus of control and individuals' subjective perceptions of the return to effort has ramifications for nearly every conceivable dimension of labor market policy. Below, I consider some of the most pressing.

The provision of benefits to the unemployed is at the core of labor market policy in many countries. The goal of the unemployment system is to allow jobseekers to maintain their consumption levels while at the same time minimizing moral hazard problems. Spinnewijn (2009) analyzes the optimal design of insurance contracts - like unemployment insurance schemes - when agents have biased beliefs about the impact of their effort (job search) in avoiding future losses (continued unemployment). Though Spinnewijn frames his discussion in the context of agents being either 'optimistic' versus 'pessimistic' in their views about the returns to effort, the distinction between an internal versus external locus of control is analogous. Any divergence between perceived and 'true' 
returns to effort has profound implications for the optimal design of insurance policies, in particular the level of insurance and the mix of publically-provided versus private insurance.

As Babcock et al. (2012) note, however, work incentives in programs like the unemployment benefits system must address not only moral hazard but also agents' self-control issues. In particular, DellaVigna and Paserman (2005) demonstrate that impatient workers set lower reservation wages and search less intensively. The overall effect of impatience on the exit rate depends on the extent to which job seekers have present-biased preferences with higher levels of impatience leading those with self-control problems to exit unemployment later.

The link between self-control and effort is also at the heart of workers' labor supply decisions more generally. One important implication of extending traditional labor supply models to accommodate the role of workers' self-control in driving effort levels is that the timing of incentives matters a great deal more. In the face of temptation and self-control issues, workers' welfare is enhanced by closing the gap between when they are paid and when they would prefer to consume (Kaur et al. 2010; Parsons and Van Wesp 2013). ${ }^{16}$ Under some circumstances, however, firms may wish to mitigate selfcontrol problems by delaying payment to employees through the use of multi-period quotas which compensate for cumulative performance (Jain 2012). Although other models predict that firms deal with workers' self-control issues by reducing the lag between effort and pay-off (e.g., Kaur et al. 2010), the larger issue remains. There is no guarantee that the timing of compensation which maximizes worker welfare also maximizes firm profits. In contrast to circumstances in which workers have time-consistent preferences and are freely able to smooth consumption across periods, self-control issues imply that the timing of pay becomes an important matter for regulation (see Parsons and Van Wesp 2013).

These sharp distinctions in the behavior of workers who differ in either their selfcontrol or locus of control make it vital that we know more about the distribution of preferences in the population as a whole. There are limits to the extent to which both firm and social policy can be individually-tailored. Instead, policy design must have in mind some notion of a representative agent while remaining cognizant of the diversity in individual preferences, and therefore behavior. In particular, the proportion of potential workers with time-consistent versus present-biased preferences will drive firms' optimal compensation policy (e.g., Gilpatric 2008), while the distribution of preferences among the unemployed shapes the design of optimal social assistance programs (e.g., Paserman 2008; Spinnewijn 2009). Resolving these issues is particularly challenging when workers' preferences are not easily observed.

Finally, one of the most important consequences of taking a behavioral approach to understanding agents' labor market decisions is that we must reconsider the welfare implications of labor market policy. In particular, behavioral models generally break the tight correspondence between choice and welfare that has guided normative welfare analysis for more than 50 years (Bernheim and Rangel 2009). If we believe that individuals' choices do not necessarily reveal information about their coherent preferences, how then can we define the social welfare function? What should be the normative benchmark we use when evaluating the welfare implications of policy initiatives? There is as yet no real consensus among economists about how to answer these questions. 
Many advocate for retaining strict neoclassical "rationality" as the normative benchmark, while others argue for applying the principle of revealed preferences selectively, rather than systematically, in order to allow for other aspects of well-being to be considered (see Bernheim and Rangel 2007 for a review). As Bernheim and Rangel (2007) note, however, the principle of revealed preferences is attractive in that it imposes a certain discipline on government interventions. "If choices do not unambiguously reveal an individual's notions of good and bad, then "true preferences" become the subject of debate, and every "beneficial" restriction of personal choice becomes fair game" (p.3). It is unclear how the set of policy leavers would be defined if revealed preferences are no longer the accepted benchmark for 'true' preferences.

\subsection{Policy to improve locus of control}

The jury is still out on whether interventions can enhance non-cognitive skills, like locus of control, thereby leading to better labor market outcomes. In their review of the literature, Almlund et al. (2011) are optimistic but note that the "evidence is consistent with effects of interventions, but there are woefully few causal studies with long-term follow-up" (p.139). ${ }^{17}$ Gutman and Schoon (2013) also urge caution, noting that "some non-cognitive skills including grit and self-control correlate strongly with outcomes but appear to be more akin to stable personality traits rather than malleable skills" (p.2).

In particular, Gutman and Schoon's (2013) recent review provides a number of useful insights into the effectiveness of interventions targeting young people's non-cognitive skills. Although they do not consider locus of control specifically, two of their findings regarding related skills are particularly relevant. First, self-efficacy is malleable, though the evidence tends to come from task-specific rather than generalized measures (p.11). Second, self-control is malleable up to age 10 but not after (p.21). Given the importance of locus of control in driving labor market outcomes, it would be useful to know whether the malleability of adolescents' locus of control is more similar to that of selfefficacy or to that of self-control.

In working-age populations, there is evidence that locus of control, like the Big Five, is stable (see Specht 2011, 2013; Cobb-Clark and Schurer 2012, 2013). However, stability is not the same thing as non-malleable, and the potential malleability (or not) of many non-cognitive skills remains an open issue, subject to a great deal of research effort. It is a debate that is important to resolve. Labor economists need to know more about the potential for labor market events, work environments, compensation schedules, and institutional arrangements to shape workers' locus of control. While providing no evidence, Miller et al. (1982) p.251, for example, conjecture that the dynamic versus stable nature of the workplace environment influences the perceptions of control of the workers employed there. If this is true, locus of control might be expected to evolve dynamically throughout individuals' careers.

The clearest evidence of a link between labor market outcomes and locus of control undoubtedly comes from Gottshalk (2005). He analyzes data from the Self-Sufficiency Project, a randomized control trial in which welfare recipients randomly received subsidies to work. These subsidies raised recipients' earnings and increased their working hours. After three years, recipients had a more internal locus of control, which - given 
the randomized design - can be interpreted as the causal effect of the subsidy. Moreover, experimental evaluations of the Perry Preschool Program indicate that persistent changes in personality, especially in externalizing (aggressive, antisocial, and rulebreaking) behavior, account for much of the long-term effects of the program on adult outcomes (Heckman et al. 2013). Thus, there may be a potential for direct intervention to improve outcomes by altering individuals' control perspectives.

The bottom line is that drawing firm conclusions about the malleability of locus of control is still very difficult. It is complicated by the fact that the literature has considered a vast range of non-cognitive skills, and very few studies focus on locus of control specifically. Moreover, there are critical periods for the development of human capabilities which vary across skills - making it important to consider not only which interventions work, but also for whom and at which ages. Importantly, evidence is emerging that many non-cognitive skills like locus of control are correlated across generations (e.g., Anger 2012) and that a mother's locus of control is linked to a vast array of child outcomes (e.g., Lekfuangfu et al. 2014). Thus, there is potential for interventions targeting locus of control to have important inter-generational consequences.

Labor economists need to invest more in understanding the potential for labor market outcomes to be improved through investments in locus of control.

\section{Conclusions}

Locus of control is emerging as one of the core determinants of labor market success. Individuals' decisions to acquire human capital, seek out new challenges, and work hard have all been linked to the extent to which they believe that what they do has consequences. As a result, firms and governments must carefully account for locus of control when designing incentive contracts, initiatives, and policies to motivate workers' behavior.

The rapidly expanding literature on the labor market consequences of locus of control is leading to new insights into the decisions that workers and firms make, how labor markets function, and what drives labor market success. Nonetheless, there remains much to do. In particular, developing a deeper understanding of four key issues would be particularly useful: i) the measurement of locus of control; ii) the mechanisms linking locus of control to labor market outcomes; iii) the magnitude of the effects of locus of control; and iv) the malleability of locus of control.

It is likely that economists will always be intrinsically more interested in locus of control as a general, rather than a context-specific, non-cognitive skill. Despite this, there is a great deal to be gained by paying more attention to the measures we are using and beginning to isolate locus of control per se from related concepts such as self-efficacy, motivation, and self-control. Though similar, these concepts are not identical, and a richer understanding of labor market behavior is likely to emerge if we are able to distinguish between them. In particular, taking more care in measurement would perhaps allow us to begin to make progress in sorting out the mechanism linking locus of control to labor market success. This is important because the optimal responses to disparity in workers' locus of control are likely to depend on whether locus of control captures expectations about investment returns, perceptions of risk, self-control problems, or motivation. 
Going forward, it will be important to develop a yardstick for benchmarking the magnitude of the effects we are observing. We need a better understanding of whether or not the effects of locus of control we are observing are economically meaningful. Without this, it is difficult to know where to focus our attention, and researchers will struggle to reach substantive conclusions. ${ }^{18}$

Finally, in most countries, ensuring that individuals' have the ability to participate productively in the labor market is at the forefront of national efforts to promote economic mobility, reduce poverty, insure households against risk, and enhance overall well-being. There is a clear relationship between locus of control and labor market success. Given this, it is imperative that we know more about the malleability of locus of control in order to assess the extent to which important social objectives can be achieved by improving individuals' locus of control.

\section{Endnotes}

${ }^{1}$ See Dohmen (2014) for an excellent review of behavioral labor economics more generally.

${ }^{2}$ Although not formally included in the Big-Five taxonomy, locus of control is related to the Big-Five factors of neuroticism and emotional stability (Almlund et al. 2011).

${ }^{3}$ See also Ng et al. (2006), who note that "some people have a dispositional tendency to believe they have more control over the external environment than others" (p.1058).

${ }^{4}$ The early psychological literature conceptualized internal and external locus of control as being opposite ends of the same spectrum (see Rotter 1954). However, factor analysis of the items in the Rotter scale often points to two factors rather than a single factor, leading some researchers to analyse separate indicators of internal versus external locus of control (e.g., Caliendo et al. 2015). At the same time, Rotter (1975) argues that factor analysis in and of itself is not useful in identifying whether the true structure of locus of control is uni- or multi-dimensional. Consequently, many economists resort to a single measure of locus of control for ease of interpretation.

${ }^{5}$ Rotter's (1966) scale included 23 items.

${ }^{6}$ Cobb-Clark and Schurer (2013) study changes in locus of control over time. They argue that researchers need to account for the changes in locus of control that may occur as a result of the ageing process (see also Heineck and Anger 2010) as well as think carefully about the nature of the error in the skill measures they use, adopting the appropriate estimation strategies to account for that error.

${ }^{7}$ The question of whether or not a lack of motivation was the main cause of poverty was central to the "culture of poverty" debate that took place in the United Sates in the late 1950s and early 1960s (Hill et al. 1985).

${ }^{8}$ Much of the seminal work of Heckman and his co-authors on non-cognitive skills have utilized the locus of control measures in these important data sources.

${ }^{9}$ Richards (1985) provides empirical evidence on the link between Rotter's (1966) locus of control scale and Rosenbaum's (1980) SCS.

${ }^{10}$ Interestingly, there is also evidence that locus of control is related to non-human capital forms of investment as well. For example, Santos (2013) finds that while land titling does not lead to increased agricultural investment on average, those with an internal locus of control do invest more after receiving property rights (Santos, 
Investment, Property Rights and Locus of Control, unpublished). Those with an internal locus of control also save more (Cobb-Clark et al. 2013).

${ }^{11}$ Cebi (2007) is not able to replicate these results using different data once cognitive ability is controlled.

${ }^{12}$ Psychologists have also developed occupation-specific locus of control measures. For example, see Rose and Medway (1981) and Skaalvik and Skaalvik (2010), who investigate the consequences of teacher locus of control.

${ }^{13}$ In his review of behavioral labor economics, Dohmen (2014) notes that although inter-temporal choices are pervasive in labor markets, models deviating from exponential discounting have not been employed on a large scale.

${ }^{14}$ Kaur et al. (2011) provide empirical evidence that many workers will choose dominated contracts that pay less for every output level - but which are steeper - in order to motivate themselves (Kaur, Kremer, Mullainathan, Self Control at Work, unpublished). This is consistent with workers having some degree of sophistication about their self-control problems.

${ }^{15}$ For excellent discussions, see Bernheim and Rangel (2009), Madrian (2014), and Schnellenbach and Schubert (2014).

${ }^{16}$ Madrian (2014) makes a similar point with respect to incentive payments designed to motivate behavioral change.

${ }^{17}$ The effectiveness of interventions to improve non-cognitive skills has been a particular focus of Heckman and his co-authors. See Almlund et al. (2011) and Heckman and Kautz (2012; 2014) for important reviews of the evidence.

${ }^{18}$ For example, see Cobb-Clark and Schurer (2013) and Boyce et al. (2013), who reach substantially different conclusions despite using the same data and finding effect sizes that are similar in magnitude.

Competing interests

The "IZA Journal of Labor Economics" is committed to the IZA Guiding Principles of Research Integrity. The author declares that she has observed these principles.

\section{Acknowledgments}

This review has benefited from helpful comments from Nicolás Salamanca and Stefanie Schurer as well as from research assistance by Melisa Bubonya. The author would like to thank the anonymous referee.

Responsible editor: Anne Gielen

Received: 25 November 2014 Accepted: 16 December 2014

Published online: 19 February 2015

\section{References}

Ajzen I (2002) Perceived behavioral control, self-efficacy, locus of control and the theory of planned behavior. J Appl Soc Psychol 32:665-683, doi:10.1111/j.15591816.2002.tb00236.x

Almlund M, Duckworth AL, Heckman J, Kautz T (2011) Personality Psychology and Economics. In: Hanushek E, Machin S, Woessman L (eds) Handbook of the Economics of Education Volume 4. North-Holland, Amsterdam, The Netherlands, pp 1-181

Andrisani P (1977) Internal-external attitudes, personal initiative, and the labor market experience of white and black men.J Jum Resour 12:308-328, doi:10.2307/145493

Andrisani P (1981) Internal-external attitudes, sense of efficacy, and labor market experience: a reply to Duncan and Morgan. J Hum Resour 16:658-666 doi:10.2307/145241

Anger S (2012) Intergenerational Transmission of Cognitive and Noncognitive Skills. In: Ermisch J, Jantti M, Smeeding T (eds) From Parents to Children: The Intergenerational Transmission of Advantage. Russell Sage Foundation, New York, pp $393-421$

Atkinson JW (1964) An Introduction to Motivation. Van Nostrand, Princeton NJ

Avtgis TA (1998) Locus of control and persuasion, social influence, and conformity: a meta-analytic review. Psycho Rep 83:899-903, doi:10.2466/pro.1998.83.3.899

Babcock L, Congdon WJ, Katz LF, Mullainathan S (2012). Notes on behavioural economics and labor market policy. IZA J Labor Policy 1(2). doi:10.1186/2193-9004-1-2

Bandura A (1977) Self-efficacy: toward a unifying theory of behavioral change. Psychol Rev 84:191-215, doi:10.1037/ 0033-295X.84.2.191 
Bandura A (1986) Social Foundations of Thought and Action. Prentice-Hall, Englewood Cliffs, NJ Bandura A (1989) Human agency in social cognitive theory. Am Psychol 44(9):1175-1184, doi:10.1037/0003-066X.44.9.1175 Bandura A (2000) Cultivate Self-Efficacy for Personal and Organizational Effectiveness. In: Locke EA (ed) The Blackwell Handbook of Principles of Organizational Behavior. Blackwell Publishers Inc, Oxford, U.K, pp 120-136

Baumeister RF, Vohs KD, Tice DM (2007) The strength model of self-control. Curr Dir Psychol Sci 16:351-355, doi:10.1111/j.1467-8721.2007.00534.x

Becker A, Deckers T, Dohmen T, Falk A, Koss F (2012) The relationship between economic preferences and psychological personality measures. Annu Rev Econ 4:453-478, doi:10.1146/annurev-economics-080511-110922

Bernheim BD, Rangel A (2007) Behavioral Public Economics: Welfare and Policy Analysis With Nonstandard DecisionMakers. In: Diamond P, Vartainen H (eds) Behavioral Economics and its Applications. Princeton University Press, New Jersey, pp 7-81

Bernheim BD, Rangel A (2009) Beyond revealed preference: choice-theoretic foundations for behavioral welfare economics. Q J Econ 124:51-104, doi:10.1162/qjec.2009.124.1.51

Borghans L, Duckworth AL, Heckman JJ, ter Weel B (2008) The economics and psychology of personality traits. J Hum Resour 43(4):972-1059

Bowles S, Gintis H, Osborne M (2001) The determinants of earnings: a behavioral approach. J Econ Lit 39(4):1137-1176, doi:10.1257/jel.39.4.1137

Boyce CJ, Wood AM, Powdthavee N (2013) Is personality fixed? Personality changes as much as 'variable' economic factors and more strongly predicts changes to life satisfaction. Soc Indic Res 111(1):287-305, doi:10.1007/s11205-012-0006-z

Caliendo M, Cobb-Clark DA, Uhlendorff A (2015) Locus of control and job search strategies. Rev Econ Stat, doi:10.1162/ REST_a_00459

Caliendo M, Fossen F, Kritikos A (2014) Personality characteristics and the decision to become and stay self-employed. Small Bus Econ 42(4):787-814, doi:10.1007/s11187-013-9514-8

Cebi M (2007) Locus of control and human capital investment revisited. J Hum Resour 42(4):919-932, doi:10.2307/ 40057334

Chan MK (2014) Welfare dependence and self-control: An empirical analysis. Working Paper 19, Economics Discipline Group, University of Technology Sydney, March.

Chiteji N (2010) Time preference, noncognitive skills, and well being across the life course: do noncognitive skills encourage healthy behavior? Am Econ Rev 100:200-204, doi:10.1257/aer.100.2.200

Clark G (1994) Factory discipline. J Econ Hist 54(1):128-163, doi:10.2307/2122694

Cobb-Clark DA, Kassenboehmer SC, Sinning MG (2013) Locus of control and savings. IZA Discussion Paper No. 7837, December. doi:10.2139/ssrn.2366519

Cobb-Clark DA, Kassenboehmer SC, Schurer S (2014) Healthy habits: the connection between diet, exercise, and locus of control. J Econ Behav Organ 98:1-28, doi:10.1016/j.jebo.2013.10.011

Cobb-Clark DA, Schurer S (2012) The stability of big-five personality traits. Econ Lett 115(1):11-15, doi:10.1016/j. econlet.2011.11.015

Cobb-Clark DA, Schurer S (2013) Two economists' musings on the stability of locus of control. Econ J 123(570):358-400, doi:10.1111/ecoj.12069

Cobb-Clark DA, Tan M (2011) Noncognitive skills, occupational attainment, and relative wages. Labour Econ 18(1):1-13, doi:10.1016/j.labeco.2010.07.003

Coleman M, DeLeire T (2003) An economic model of locus of control and the human capital investment decision. J Hum Resour 38(3):701-721, doi:10.2307/1558773

DellaVigna S (2009) Psychology and economics: evidence from the field. J Econ Lit 47(2):315-372, doi:10.1257/jel.47.2.315

DellaVigna S, Paserman MD (2005) Job search and impatience. J Labor Econ 23(3):527-588, doi:10.1086/430286

Dohmen T (2014) Behavioural labour economics: advances and future extensions. Labour Econ 30:71-85, doi:10.1016/j. labeco.2014.06.008

Duckworth AL, Kern ML (2011) A meta-analysis of the convergent validity of self-control measures. J Res Pers 45(3):259-268, doi:10.1016/j.jp. 2011.02.004

Duncan GJ, Dunifon R (1998) Soft Skills and Long run Labor Market Success. In: Polochek S (ed) Research in Labor Economics. JAI Press, Stamford, Conn, pp 123-129

Dunifon R, Duncan GJ (1998) Long-run effects of motivation on labor-market success. Soc Psychol Quart 61(1):33-48, doi:10.2307/2787056

Esteban S, Miyagawa E, Shum M (2007) Nonlinear pricing with self-control preferences. J Econ Theory 135:306-338, doi:10.1016/j.jet.2006.04.007

Furnham A (1986) Economic locus of control. Human Relat 39(1):29-43, doi:10.1177/001872678603900102

Gallo WT, Endrass J, Bradley EH, Hell D, Kasl SV (2003) The influence of internal control on the employment status of German workers. Schmollers Jahr 123:71-82, doi:10.3790/schm.133.2.215

Gilpatric SM (2008) Present-biased preferences, self-awareness, and shirking. J Econ Behav Organ 67:735-754, doi:10.1016/j.jebo.2007.05.004

Goldsmith AH, Veum JR, Darity W Jr (1996) The psychological impact of unemployment and joblessness. J of SocioEcon 25(3):333-358, doi:10.1016/S1053-5357(96)90009-8

Goldsmith AH, Veum JR, Darity W Jr (1997) The impact of psychological and human capital on wages. Econ Inq 35:815-829, doi:10.1111/j.1465-7295.1997.tb01966.x

Goldsmith AH, Veum JR, Darity W Jr (2000) Motivation and labor market outcomes. In: Polachek S, Tatsiramos K (ed) Research in Labor Economics (Volume 19). Emerald Group Publishing Limited, pp 109-146. doi:10.1016/S0147-912 (00) $19006-5$

Gottshalk P (2005) Can work alter welfare recipients' beliefs? J Policy Anal Manag 24(3):485-498, doi:10.1002/pam.20111

Gutman LM, Schoon I (2013) The Impact of non-Cognitive Skills on Outcomes for Young People: Literature Review. Education Endowment Foundation, London, Available at http://hdl.voced.edu.au/10707/287500. Accessed 11 November 2014 
Hansemark OC (2003) Need for achievement, locus of control and the prediction of business start-ups: a longitudinal study. J Econ Psychol 24:301-319, doi:10.1016/S0167-4870(02)00188-5

Heckman J, Kautz T (2012) Hard evidence on soft skills. Labour Econ 19:451-464, doi:10.1016/j.labeco.2012.05.014

Heckman J, Kautz T (2014) Fostering and Measuring Skills Interventions That Improve Character and Cognition. In: Heckman JJ, Humphries JE, Kautz T (eds) The GED Myth: Education, Achievement Tests, and the Role of Character in American Life. University of Chicago Press, Chicago, IL, pp 341-430

Heckman J, Pinto R, Savelyev P (2013) Understanding the mechanisms through which an influential early childhood program boosted adult outcomes. Am Econ Rev 103(6):2052-2086, doi:10.1257/aer.103.6.2052

Heckman J, Stixrud J, Urzua S (2006) The effects of cognitive and noncognitive abilities on labor market outcomes and social behavior. J Labor Econ 24:411-482, doi:10.1086/504455

Heineck G, Anger S (2010) The returns to cognitive abilities and personality traits in Germany. Labour Econ 17:535-546, doi:10.1016/j.labeco.2009.06.001

Heller M (2005) Court ruling that employer's integrity test violated ADA could open door to litigation. Workforce Manag 84(9):74-77

Hill MS, Augustyniak S, Duncan GJ, Gurin G, Gurin P, Liker JK, Morgan JN, Pnza M (1985) Motivation and Economic Mobility (Research Report Series). Institute for Social Research, The University of Michigan, Ann Arbor

Hsu C (2004) The testing of America. US News and World Report 137(9):68-69

Jain S (2012) Self-control and incentives: an analysis of multiperiod quota plans. Market Sci 31(5):855-869, doi:10.1287/ mksc. 1120.0714

Judge TA, Bono JE (2001) Relationship of core self-evaluations traits—self-esteem, generalized self-efficacy, locus of control, and emotional stability—with job satisfaction and job performance: a meta-analysis. J Appl Psychol 86:80-92, doi:10.1037/0021-9010.86.1.80

Judge TA, Bono JE, Locke EA (2000) Personality and job satisfaction the mediating role of job characteristics. J Appl Psychol 85(2):237-249, doi:10.1037/0021-9010.85.2.237

Judge TA, Erez A, Bono JE, Thoresen CJ (2002) Are measures of self-esteem, neuroticism, locus of control, and generalized self-efficacy indicators of a common core construct? J Pers Soc Psychol 83:693-710, doi:10.1037/00223514.83.3.693

Judge TA, Erez A, Bono JE, Thoresen CJ (2003) The core self-evaluations scale: Development of a measure. Pers Psychol 56:303-331, doi:10.1111/j.1744-6570.2003.tb00152.x

Judge TA, Hurst C (2007) Capitalizing on one's advantages: Role of core self-evaluations. J Appl Psychol 92(5):1212-1227, doi:10.1037/0021-9010.92.5.1212

Kaplan SE, Reneau JH, Whitecotton S (2001) The effect of predictive ability information, locus of control, and decision maker involvement on decision aid reliance. J Behav Decis Making 14:35-50, doi:10.1002/1099-0771(200101)14:1 < 35::AID-BDM364 > 3.0.CO;2-D

Kaur S, Kremer M, Mullainathan S (2010) Self-control and the development of work arrangements. Am Econ Rev 100 (2):624-628, doi:10.1257/aer.100.2.624

Kaur S, Kremer M, Mullainathan S (2011) Self-control at work. Unpublished working paper, available at www.princeton.edu Laibson D (1997) Golden eggs and hyperbolic discounting. J Econ 112(2):443-477, doi:10.1162/003355397555253

Lee DS, McCray J (2005) Crime, punishment, and myopia. NBER WP 11491, National Bureau of Economic Research. doi:10.3386/w11491

Lefcourt HM (1992) Durability and impact of the locus of control construct. Psycho Bull 112(3):411-414, doi:10.1177/ 1066480713515160

Lekfuangfu, WN, Cornaglia, F, Powdthavee, N, Warrinnier, N (2014) Locus of control and its intergenerational implications for early childhood skill formation. IZA Discussion Paper 8487.

Levin L (1998) Are assets fungible? Testing the behavioral theory of life-cycle savings. J Econ Behav Organ 36:59-83, doi:10.1016/S0167-2681(98)00070-5

Madrian BC (2014) Applying insights from behavioral economics to policy decisions. Annu Rev Econ 6:663-688, doi:10.1146/annurev-economics-080213-041033

McGee A (2014) How the perception of control influences unemployed job search. Ind Labor Relat Rev, doi:10.1177/ 0019793914556245

McGee A, McGee P (2011) Search, effort, and locus of control. IZA Discussion Paper No. 5948, August, available at http://ftp.iza.org/dp5948.pdf

Mendolia S, Walker I (2014a) The effect of noncognitive traits on behaviours in adolescence. Health Econ 23(9):1146-1158, doi:10.1002/hec.3043

Mendolia S, Walker I (2014b) The effect of personality traits on subject choice and performance in high school: Evidence from an English cohort. Econ Educ Rev 43:47-65

Miller DM, De Vries MFRK, Toulouse JM (1982) Top executive locus of control and its relationship to strategy-making, structure, and environment. Acad Manag J 25(2):237-253, doi:10.2307/255988

Mount MK, Barrick MR (1998) Five reasons why the big five article has been frequently cited. Pers Psychol 51:849-857, doi:10.1111/j.1744-6570.1998.tb00743.x

$\mathrm{Ng}$ TWH, Sorensen KL, Eby LT (2006) Locus of control at work: a meta-analysis. J Organ Behav 27(8):1057-1087, doi:10.1002/job.416

O’Donoghue T, Rabin M (1999) Doing it now or later. Am Econ Rev 89(1):103-124, doi:10.2307/116981

Offerhaus J (2013) The type to train: Impacts of personality characteristics on further training participation. SOEP Discussion Paper No. 531, available at www.diw.de/documents/publikationen/73/diw_01.c.414552.de/ diw_sp0531.pdf

Osborne M (2000) The power of personality: Labor market rewards and the transmission of earnings. PhD Dissertation, University of Massachusetts Amherst.

Osborne Groves M (2005) How important is your personality? Labor market returns to personality for women in the US and UK. J Econ Psychol 26:827-841, doi:10.1016/j.joep.2005.03.001

Parsons CA, Van Wesep ED (2013) The timing of pay. J Financ Econ 109:373-397, doi:10.1016/j.jfineco.2013.03.005 
Paserman MD (2008) Job search and hyperbolic discounting: Structural estimation and policy evaluation. Econ J 18 (531):1418-1453, doi:10.1111/j.1468-0297.2008.02175.x

Pearlin LI, Schooler C (1978) The structure of coping. J Health Soc Behav 19(1):2-21, doi:10.2307/2136319

Piatek R, Pinger P (2010) Maintaining (locus of) control? Assessing the impact of locus of control on education decisions and wages. IZA Discussion Paper 5289, available at http://ftp.iza.org/dp5289.pdf

Richards PS (1985) Construct validation of the self-control schedule. J Res Pers 19:208-218, doi:10.1016/0092-6566(85)90029-7

Rose JS, Medway FJ (1981) Teacher locus of control, teacher behavior, and student behavior as determinants of student achievement. J Educ Res 74(6):375-381, doi:10.2307/27539844

Rosenbaum M (1980) A schedule for assessing self-control behaviors: preliminary findings. Behav Ther 11:109-121, doi:10.1016/S0005-7894(80)80040-2

Rothstein MG, Goffin RD (2006) The use of personality measures in personnel selection: what does current research support? Hum Resour Manage R 16:155-180, doi:10.1016/j.hrmr.2006.03.004

Rotter JB (1966) Generalized expectancies of internal versus external control of reinforcements. Psychol Monogr 80(1):1-28, doi:10.1037/h0092976

Rotter JB (1990) Internal versus external control of reinforcement: a case history of a variable. Am Psychol 45(4):489-493, doi:10.1037/0003-066X.45.4.489

Rotter JB (1954) Social Learning and Clinical Psychology. Prentice-Hall, Englewood Cliffs, NJ

Rotter JB (1975) Some problems and misconceptions related to the construct of internal versus external control of reinforcement. J Consult Clinic Psy 43(1):56-67

Ruhm CJ (2012) Understanding overeating and obesity. J Health Econ 31:781-796, doi:10.1016/j.jhealeco.2012.07.004

Salamanca N, Grip A, Fourage D, Montizaan R (2015) Locus of control and investment in risky assets. In: Salamanca N, Economic preferences and risk taking. Dissertation, Maastricht University

Santos P (2013) Investment, property rights, and locus of control. Unpublished working paper, Monash University.

Schnellenbach J, Schubert C (2014) Behavioral political economy: A survey. CESifo Working Paper 4988, September, available at SSRN: http://ssrn.com/abstract=2507739

Schnitzlein DD, Stephani J (2013) Locus of control and low-wage mobility. SOEP Working Paper 589, DIW, available at www.diw.de/documents/publikationen/73/diw_01.c.429214.de/diw_sp0589.pdf

Schurer S (2014) Bouncing back from health shocks: Locus of control, labor supply, and mortality. IZA Discussion Paper 8203, May, available at http://ftp.iza.org/dp8203.pdf

Selart M (2005) Understanding the role of locus of control in consultative decision-making: A case study. Manag Decis 43(3):397-412, doi:10.1108/00251740510589779

Semykina A, Linz SJ (2007) Gender differences in personality and earnings: evidence from Russia. J Econ Psychol 28:387-410, doi:10.1016/j.joep.2006.05.004

Shefrin HM, Thaler RH (1988) The behavioral life-cycle hypothesis. Econ Inq 26(4):609-643, doi:10.1111/j.1465-7295.1988. tb01520.x

Skaalvik EM, Skaalvik S (2010) Teacher self-efficacy and teacher burnout: a study of relations. Teach Teach Educ 26:1059-1069, doi:10.1016/j.tate.2009.11.001

Skinner EA (1995) Perceived Control, Motivation, and Coping. Sage Publications, Thousand Oaks, CA

Skinner EA (1996) A guide to constructs of control. J Pers Soc Psychol 71(3):549-570, doi:10.1037/0022-3514.71.3.549

Specht J, Egloff B, Schmukle SC (2011) Stability and change of personality across the life course: the impact of age and major life events on mean-level and rank-order stability of the big five. J Pers Soc Psychol 101(4):862-882, doi:10.1037/a0024950

Specht J, Egloff B, Schmukle SC (2013) Everything under control? The effects of age, gender, and education on trajectories of perceived control in a nationally representative German sample. Dev Psychol 49(2):353-364, doi:10.1037/a0028243

Spector PE (1982) Behavior in organizations as a function of employees' locus of control. Psychol Bull 91(3):482-497, doi:10.1037/0033-2909.91.3.482

Spector PE (1988) Development of work locus of control scale. J Occup Psychol 61:335-340, doi:10.1111/j.20448325.1988.tb00470.x

Spinnewijn J (2009) Unemployed but optimistic: Optimal insurance design with biased beliefs. J Eur Econ Assoc. doi:10.1111/jeea.12099

Stabile SJ (2002) The use of personality tests as a hiring tool: is the benefit worth the cost? J Bus Law 4(2):279-313, Available at http://scholarship.law.upenn.edu/jbl/vol4/iss2/1

Steptoe A, Wardle J (2001) Locus of control and health behaviour revisited: a multivariate analysis of young adults from 18 countries. Brit J Psychol 92:659-672, doi:10.1348/000712601162400

Thaler RH, Shefrin HM (1981) An economic theory of self-control. J Polit Econ 89(2):392-406, doi:10.2307/1833317

Uhlendorff A (2004) Der einfluss von persönlichkeitseigenschaften und sozialen ressourcen auf die arbeitslosigkeitsdauer. Kolner Zeitschrift Fur Soziologie Und Sozialpsychologie 56:279-303, doi:10.1007/s11577-004-0035-y

Van Praag, M, Van Witteloostuijn, A, Van der Sluis, J (2009) Returns for Entrepreneurs vs. Employees: The Effect of Education and Personal Control on the Relative Performance of Entrepreneurs vs. Wage Employees. IZA Discussion Paper 4628.

Wang LY, Kick E, Fraser J, Burns TJ (1999) Status attainment in America: the roles of locus of control and self-esteem in educational and occupational outcomes. Sociol Spectrum 19:281-298, doi:10.1080/027321799280163

Wang Q, Bowling N, Eschleman KJ (2010) A meta-analytic examination of work and general locus of control. J Appl Psychol 95(4):761-768, doi:10.1037/a0017707

Wallston KA, Wallson BS, DeVellis R (1978) Development of the multidimensional health locus of control (MHLC) scales. Health Educ Behav 6:160-170, doi:10.1177/109019817800600107 